\title{
Pengenalan Literasi Komputer dan E-PPGBM pada Kader Posyandu Cendrawasih
}

\author{
Endah Widati $^{{ }^{*}}{ }$ Zeinora $^{2}$, Fadjriah Hapsari ${ }^{3}$ \\ ${ }^{123}$ Pendidikan Ekonomi, Fakultas Ilmu Pendidikan dan Pengetahuan Sosial, \\ E-mail*: endahwidati82@gmail.com
}

\begin{tabular}{ll}
\hline Article History: & Abstrak: \\
Received: Desember & Aplikasi e-PPGBM merupakan aplikasi yang \\
2020 & digunakan para pengurus dan kader posyandu \\
Revised: Desember & untuk melakukan pencatatan dan pelopran \\
2020 & status gizi ibu dan anak setiap kali melakukan \\
Accepted: Juni 2021 & kegiatan utama. Banyaknya pengurus dan \\
Available online: Juni & kader posyandu yang berada pada masa emas \\
2021 & (40 tahun keatas) membuat aplikasi ini dirasa \\
& mempersulit para pengurus dan kader. Hal ini \\
& karena para pengurus dan kader memiliki \\
Kata Kunci: e- & pengetahuan yang minim akan teknologi. \\
PPGBM, komputer, & Pelatihan ini mengggunakan metode klasikal \\
literasi komputer, & dengan target peserta adalah 30 kader \\
Posyandu, & posyandu. Adapun hasil dari pelatihan ini \\
& adalah peningkatan pemahaman para kader \\
& mengenai pengisian e-ppgbm secara \\
& terkomputerisasi. Dilihat dari peserta latihan \\
& yang mayoritas berusia 40-60 tahun, maka \\
perlu adanya sosialisasi langsung berupa \\
seminar dan pelatihan intensif kepada kader \\
posyandu terutama teknologi seperti e- \\
PPGBM.
\end{tabular}




\section{Pendahuluan}

Anak adalah generasi penerus yang harus diperhatikan secara seksama. Kesalahan pada perkembangan sejak lahir akan berakibat fatal bagi masa depannya. Akibat fatal tersebut tidak hanya berpengaruh bagi dirinya sendiri namun juga bagi orang tua, orang di sekitar dan juga negara. Seribu hari pertama merupakan fase emas bagi anak-anak yang baru dilahirkan (Priyatna, 2014). Salah satu yang menjadi perhatian adalah tumbuh kembang anak, baik secara fisik maupun mental atau psikologis atau dengan kata lain tumbuh kembang anak bersifat kuantitatif dan kualitatif. Secara fisik, anak-anak harus berkembang sesuai usianya baik dari sisi tinggi badan (Setiawan, Machmud, \& Masrul, 2018), berat badan dan ukuran kepala. Dengan kata lain, perkembangan anak secara fisik bersifat kuantitatif atau dapat diukur berdasarkan angka. Namun pada kenyataan pertumbuhan anak pada usia emas, yaitu 0 - 5 tahun, tidak sesuai dengan yang seharusnya, hal ini disebabkan banyak faktor.

Gizi merupakan faktor penentu tumbuh kembang anak secara fisik. Pada saat bayi masih dalam kandungan, maka gizi yang diperoleh dari asupan makanan sang ibu pada saat hamil (Kusumawati, Rahardjo, \& Sari, 2016). Masalah gizi merupakan masalah yang paling rumit karena berkaitan dengan berbagai aspek seperti pengetahuan, tingkat kesejahteran atau ekonomi dari orang tua si bayi. Kekurang gizi tidak hanya berdampak negatif bagi perkembangan fisik tetapi juga masa depan si anak, hal ini karena kekurangan gizi akan mempengaruhi perkembang otak baik secara ukuran maupun kemampuan. Berdasarkan hasil kajian UNICEF (2012) menunjukkan bahwa kekurangan gizi pada anak akan membuat anak tumbuh menjadi anak pendek yang kemungkinan kelak dimasa yang akan datang anak tumbuh menjadi orang dewasa yang kurang berpendidikan, miskin, kurang sehat dan lebih rentan pada penyakit tidak menular. Tercatat 150,8 milyar anak dibawah usia 5 tahun menderita stunting(WHO; UNICEF; World Bank Group, 2018). Dari jumlah tersebut Asia berada diperingkat pertama dengan jumlah total 83,6 milyar anak $(55,44 \%)$. Di Indonesia, jumlah anak balita penderita stunting sebanyak 7,8 juta jiwa $(35,6 \%)$ (Susilawaty \& Yulianto, 2018) 
DKI Jakarta sebagai ibu kota negara juga tidak terlepas dari masalah gizi buruk. Dilihat dari kategori indeks berat badan per tinggi badan usia $0-59$ bulan 2,6\% dinyatakan sangat kurus dan 7,3\% dinyatakan kurus. Adapun penyebab gizi buruk masih terjadi di DKI Jakarta karena minimnya pengetahuan warga mengenai gizi. Jakarta Timur merupakan salah satu kota administratif di wilayah DKI Jakarta yang memiliki penduduk sebanyak \pm $2,894,730$ jiwa dengan total $\pm 280,580$ jiwa berusia antara $0-4$ tahun. Penemuan kasus gizi buruk di Rawamangun, Jakarta Timur dan Jakarta Utara membuat pemerintah kota sadar bahwa gizi buruk merupakan masalah yang mudah dan sederhana, perlu banyak dukungan dari berbagai pihak untuk dapat mengatasi masalah tersebut.

Sejak dicetuskan pada tahun 1986, Posyandu berperan sebagai pusat pelayanan kesehatan dasar bagi ibu dan balita (Tim Nasional Percepatan Penanggulangan Kemiskinan, 2017) dan menjadi salah satu sumber pengetahuan bagi para ibu mengenai tumbuh kembang anak baik secara fisik maupun psikologis melalui program intervensi gizi (Iswarawanti, 2010). Namun pemanfaatan Posyandu sebagai pusat pelayanan kesehatan dasar bagi ibu dan anak masih kurang, hal ini dapat dilihat dari jumlah ibu dan anak yang mengunjungi posyandu dengan berbagai alasan (Sulistiyanti \& Untariningsih, 2013; Djamil, 2017), serta kurangnya pegetahuan kader posyandu karena memiliki latar belakang yang berbeda (Hardiyanti, Jus'at, \& Angkasa, 2018).

Seiring perkembangan teknologi, pelaporan yang awalnya dilakukan secara manual sekarang beralih dengan laporan hasil pemantauan program intervensi gizi berbasis teknologi. Adapun teknologi yang diterapkan berupa sistem pencatatan dan pelaporan berbasis masyarakat dengan teknologi elektronik yaitu aplikasi e-PPGBM (electronic Pencatatan dan Pelaporan Gizi Berbasis Masyarakat). Penerapan aplikasi ini dikarenakan karena data status gizi masyarakat menjadi kebutuhan data di daerah atau wilayah tertentu untuk mengetahui besar masalah gizi yang ada sebagai dasar perencanaan kegiatan, evaluasi kinerja dan intervensi yang akan dilakukan oleh pemangku kepentingan. Penerapan teknologi dalam kebiasaan kerja di sebuah organisasi dapat meningkatkan efektifitas kerja individu (Najoan \& Tulusan, 2015). Namun pengunaan komputer dan telepon pintar sebagai media aplikasi e- 
PPGBM menjadi salah satu kendala bagi kader di Posyandu Cendrawasih karena para kader termasuk pada generasi emas yaitu usia 40-60 tahun yang kurang familiar dengan kedua perangkat tersebut yang akhirnya menyebabkan para kader bergantung sekali kepada anggota keluarga untuk dapat melakukan input hasil laporan kegiatan sehingga adakalanya laporan terlambat di input.

\section{Metode}

Kegiatan ini dilakukan dalam bentuk pelatihan dengan metode pembelajaran partisipatif melalui metode presentasi, demonstrasi dan simulasi serta pendampingan dengan memberikan 2 jenis materi utama yaitu dasardasar komputer dan telepon seluler, serta teknik pengisian e-PPGBM. Pelatihan ini awalnya ditargetkan untuk diikuti oleh 30 orang kader Posyandu Cendrawasih, namun pada saat realisasinya hanya 11 orang peserta saja yang mengikuti, dengan rata-rata usia diatas 40 tahun

\section{Hasil}

Berdasarkan hasil observasi awal terdapat beberapa temuan terkait pemahaman untuk menggunakan telepon pintar yaitu bahwa 11 peserta mengerti cara menyalakan dan matikan telepon seluler, melakukan panggilan telepon, mengirim pesan melalui sms, Jika dilihat dari pertanyaan yang diajukan seperti apakah peserta mengerti bagaimana mengirim pesan melalui aplikasi WA hanya 4 peserta yang mengerti sedangkan 7 peserta lain tidak mengerti, dan biasanya meminta bantuan pada anak atau cucu yang ada didekat para peserta. Untuk menyimpan nomor telepon, 6 peserta menyatakan mengerti caranya sedangkan 5 peserta lain tidak mengerti. Sedangkan untuk mengunakan aplikasi selain yang sudah ditanyakan sebelumnya hanya 3 orang yang mengerti sedangkan 8 peserta lainnya tidak mengerti. Ke 3 peserta yang mengerti penggunaan aplikasi lain seperti kamera, mobile banking, buku kas dan online shopping. Untuk melakukan pengunduhan aplikasi baru para peserta mengemukakan bahwa biasanya meminta bantuan anak atau cucu atau bahkan orang yang menyarankan aplikasi tersebut. Walaupun sudah diunduh malah tidak digunakan. Dari hasil jawaban peserta menunjukkan bahwa pengetahuan peserta mengenai penggunaan telepon seluler baik fitur maupun aplikasi yang tersedia masih sangat minim. 
Untuk hasil observasi awal tentang pengetahuan peserta mengenai komputer hanya pada proses mematikan dan menghidupkan komputer. Itu pun hanya 3 orang saja diantar peserta sedangkan yang lain tidak mengerti baik perangkat keras komputer, menyalakan dan mematikan komputer, aplikasi Microsoft dan melakukan installasi program. Hal ini dapat dimaklumi bahwa para kader selain usia yang sudah lanjut umumnya memiliki latar belakang pendidikan yang tidak tinggi, hanya sebatas sekolah menengah atas. Dengan usia yang tidak muda dan latar belakang pendidikan yang hanya sekolah menengah atas dapat dipahami bahwa ketidak mengertian peserta akan komputer menjadi kendala saat ketika akan menjalankan tanggung jawab sebagai kader posyandu. Dengan alasan inilah, maka tim berinisiatif memberikan pelatihan mengenai literasi komputer dan e-PPGBM sebagai aplikasi untuk membuat laporan agar data terintegrasi dengan baik.

Setelah melakukan observasi awal dengan melakukan tanya jawab dengan peserta, tim memberikan materi seputar komputer dan aplikasi ePPGBM pada smartphones. Adapun materi yang diberikan mencakup pengetahuan hardware dan software meliputi Microsoft office yaitu word dan excel serta aplikasi e-PPGBM. Setelah memberikan materi tetang fitur HP, komputer dan juga aplikasi e-PPGBM, maka tim melakukan evaluasi. Evaluasi dilakukan dengan cara memberikan post test berupa 20 aktivitas terkait materi yang sudah diberikan. Tabel 1 menunjukan hasil dari post test yang sudah dilakukan.

Tabel 1. Hasil Evaluasi

\begin{tabular}{clcc}
\hline No. & \multicolumn{1}{c}{ Aktivitas } & Benar & Salah \\
\hline 1. & Mengirim Pesan melalui aplikasi WA & $100 \%$ & $0 \%$ \\
\hline 2. & Mengunduh aplikasi pada telepon seluler & $100 \%$ & $0 \%$ \\
\hline 3. & Menggunakan aplikasi yang sudah diunduh & $100 \%$ & $0 \%$ \\
\hline 4. & Mengirim file melalui aplikasi WA & $91 \%$ & $9 \%$ \\
\hline 5. & Mengirim foto melalui aplikasi WA & $82 \%$ & $18 \%$ \\
\hline 6. & Menggunakan berbagai fitur telepon seluler & $64 \%$ & $36 \%$ \\
\hline 7. & Mengenal perangkat keras komputer & $82 \%$ & $18 \%$ \\
\hline 8. & Menyalakan komputer & 100 & $0 \%$ \\
\hline 9. & Mematikan komputer & $100 \%$ & $0 \%$ \\
\hline
\end{tabular}




\begin{tabular}{clcc}
\hline 10. & Membuka program pada komputer & $100 \%$ & $0 \%$ \\
\hline 11. & Mengunduh progam pada komputer & $82 \%$ & $18 \%$ \\
\hline 12. & Menginstall program pada komputer & $82 \%$ & $18 \%$ \\
\hline 13. & Membuat dokumen pada program Word & $55 \%$ & $45 \%$ \\
\hline 14. & Membuat dokumen pada program Excel & $55 \%$ & $45 \%$ \\
\hline 15. & Menyimpan dokumen pada program Word & $100 \%$ & $0 \%$ \\
\hline 16. & Menyimpan dokumen pada program Excel & $100 \%$ & $0 \%$ \\
\hline 17. & Mengunduh aplikasi E-PPGBM & $82 \%$ & $18 \%$ \\
\hline 18. & Menginstall aplikasi E-PPGBM & $55 \%$ & $45 \%$ \\
\hline 19. & Mengisi setiap informasi pada aplikasi E-PPGBM & $100 \%$ & $0 \%$ \\
\hline 20. & Menyimpan data pada aplikasi E-PPGBM & $100 \%$ & $0 \%$ \\
\hline
\end{tabular}

Sumber: Data diolah (2019)

\section{Diskusi}

Berdasarkan buku pedoman umum pengelolaan Posyandu (Kementerian Kesehatan RI, 2011) secara umum Posyandu bertujuan untuk menunjang percepatan penurunan Angka Kematian lbu (AKI), Angka Kematian Bayi (AKB) dan Angka Kematian Anak Balita (AKABA) di Indonesia melalui upaya pemberdayaan masyarakat dan secara khusus meningkatkan peran masyarakat dalam penyelenggaraan upaya kesehatan dasar dan meningkatkan cakupan dan jangkauan pelayanan kesehatan dasar untuk seluruh masyarakat dengan fokus utama bayi, anak balita, ibu hamil, ibu nifas, ibu menyusui dan Pasangan Usia Subur (PUS).

Posyandu merupakan Upaya Kesehatan Bersumber Daya Masyarakat (UKBM) yang dikelola dan diselenggarakan dari, oleh, untuk dan bersama masyarakat dalam penyelenggaraan pembangunan kesehatan. (Kementerian Kesehatan RI, 2011) sehingga Posyandu juga berperan aktif sebagai organisasi masyarakat dalam pembangunan kesehatan masyarakat (Tse, Suprojo, \& Adiwidjaja, 2017). Sehigga dalam pengelolaannya, posyandu memerlukan kesediaan masyarakat sekitar untuk dapat menjalankan program yang telah ditentukan oleh pemerintah Kegiatan Posyandu terbagi atas 2 jenis (Kementerian Kesehatan RI, 2011) yaitu kegiatan utama seperti pelayanan kesehatan Ibu dan anak, keluarga berencana, imunisasi, gizi serta pencegahan dan penanggulangan diare, biasanya dilakukan minimal 1 bulan 1 kali dan 
kegiatan tambahan seperti, bina keluarga balita, kelas ibu hamil dan balita, pos pendidikan anak usia dini dan lain sebagainya, dilakukan sesuai dengan kesepakatan kader, pengurus dan tokoh masyarakat. Setiap pelaksanakaan kegiatan baik utama maupun tambahan.

Dimasa lalu laporan hasil kegiatan posyandu dibuat secara manual menggunaan lembar kerja yang sudah disiapkan, sehingga kader dan pengurus posyandu dapat menggunakannya hanya dengan mencatat pada kolom yang sudah tersedia. Perubahan teknologi dan juga 1 dari 10 pesan Presiden Joko Widodo pada saat RAKER KESNAS 2017 yang menyatakan bahwa gizi merupakan investasi bangsa sehingga harus dilakukan Surveilans gizi dan pemantauan status gizi balita dan ibu hamil harus dilakukan secara rutin dan real time (Putri, 2018). Sehingga dibutuhkan tools atau alat bantu yang dapat digunakan untuk memberikan informasi tersebut, tentunya proses input atas tools yang dimaksud harus sesuai dengan identitas dan alamat individu yang dipantau.

Electronic-Pencatatan dan Pelaporan Gizi Berbasis Masyarakat (ePPGBM) disosialisasikan di pertengahan tahun 2018 yang berfungsi sebagai alat pencatatan dan pelaporan gizi berbasis teknologi untuk membantu kader dan pengurus posyandu untuk dapat mengetahui kondisi dan status ibu dan anak di daerah yang merupakan tanggung jawabnya. E-PPGBM merupakan aplikasi berbasis teknologi yang harus dipelajari oleh setiap kader dan pengurus. Sebagai perpanjangan tangan pemerintah untuk membangun kesehatan masyarakat, mau tidak mau Posyandu perlu mengaplikasikan EPPGBM dalam melakukan pencatatan dan pelaporan sehingga data terintegrasi di seluruh Indonesia.

Sebagai kader dan pengurus Posyandu, yang berasal dari latar belakang yang berbeda, baik dari sisi pendidikan, pengalaman juga pengetahuan membuat kemampuan setiap individu berbeda baik terhadap kemampuan akan kegiatan utama maupun kegiatan admistrasi pendukung. Selain itu kinerja masing - masing kader dan pengurus juga dipengaruhi berbagai hal (Yanti \& Kartini Hasballah, 2016; Wirapuspita, 2013), salah satunya latar belakang pendidikan dan pengalaman mengelola posyandu (Profita, 2018; Hardiyanti et al., 2018) 
Sebagai salah satu Posyandu di wilayah administrasi kota Jakarta Timur, Posyandu Cendrawasih juga diwajibkan menggunkan E-PPGBM dalam melalukan pencatatan dan pelaporan status gizi dan kondisi Ibu dan Anak di wilayah RW 10, Kelurahan Ciracas Jakarta Timur. Seperti umumnya pengurus dan kader Posyandu lain, pengurus dan Kader Posyandu Cendrawasih juga miliki latar belakang dan pendidikan yang berbeda. Sehingga penerapan EPPGBM dirasa cukup menyulitkan. Pengurus dan Kader Posyandu rata-rata berusia diantara 40 - 65 tahun dengan pendidikan akhir setara sekolah menengah atas (SMA). Sosialisasi yang dirasa cukup cepat tidak memungkinkan untuk para pengurus dan kader mampu memahami cara kerja menggunakan e-PPGBM hal ini terlihat dari pemahaman yang dimiliki para pengurus dan kader terkait literasi komputer dan e-PPGBM yang masih rendah. Walaupun dianggap dan terbukti bahwa penerapan e-PPGBM sangat efektif dan efisien untuk mendapatkan data secara akurat mengenai kondisi ibu dan anak pada suatu daerah seperti yang tercatat dalam beberapa penelitian yang dilakukan seperti aksi konvergensi percepatan penurunan stunting di Kabupaten Manggarai Barat, NTT (Picauly, Mboeik, Lendes, \& Hayer, 2020), dimana penangangan gizi buruk sesuai dengan hasil penilaian e-PPGBM. Serta dampak pandemik covid19 beresiko menjadi salah satu penyebab stunting di Bangka Belitung dikarenakan perubahan pola sosial ekonomi termasuk salah satunya adalah akses layanan kesehatan berdasarkan analisis data e-PPBGM. (Efrizal, 2020)

\section{Kesimpulan}

Berdasarkan kegiatan yang sudah berjalan disimpulkan bahwa bertambahnya pengetahuan para peserta mengenai komputer dan e-ppgbm membantu para kader untuk mengetahui semua informasi mengenai data balita dan sasaran posyandu secara umum dalam e-PPGBM. Adapun saran yang diajukan adalah perlu adanya sosialiasasi dari permerintah pusat dan daerah didukung tim sukarelawan secara periodik mengingat aplikasi eppbgm belum digunakan secara optimal di beberapa wilayah dan memastikan bahwa setiap posyandu memiliki program kaderisasi sehingga hal-hal yang berkaitan dengan administrasi dapat dilakukan oleh kader yang lebih muda usianya. 


\section{Pengakuan/Acknowledgements}

Terima kasih kepada Ibu-Ibu PKK dan Kader Posyandu Cendrawasih.

\section{Daftar Referensi}

Djamil, A. (2017). Faktor-faktor yang berhubungan dengan perilaku ibu balita menimbang anaknya ke posyandu. Jurnal Kesehatan, 8(1), 127-134.

Efrizal, W. (2020). Berdampakkah Pandemi Covid-19 terhadap Stunting di Bangka Belitung? Jurnal Kebijakan Kesehatan Indonesia: JKKI, 9(3), 154-157.

Hardiyanti, R., Jus'at, I., \& Angkasa, D. (2018). Hubungan lama kerja menjadi kader, pengetahuan, pendidikan, pelatihan dengan presisi dan akurasi hasil penimbangan berat badan balita oleh kader Posyandu. AcTion: Aceh Nutrition Journal, 3(1), 74-81.

Iswarawanti, D. N. (2010). Kader posyandu: Peranan dan tantangan pemberdayaannya dalam usaha peningkatan gizi anak di indonesia. Jurnal Manajemen Pelayanan Kesehatan, 13(04).

Kementerian Kesehatan RI. (2011). Pedoman Umum Pengelolaan Posyandu. Jakarta: Kementerian Kesehatan RI. Retrieved from https://promkes.kemkes.go.id

Kusumawati, E., Rahardjo, S., \& Sari, H. P. (2016). Upaya perbaikan gizi 1000 hari pertama kehidupan dalam rangka pencegahan stunting balita melalui optimalisasi peran tenaga gizi di Kabupaten Banyumas. Kesmas Indonesia: Jurnal Ilmiah Kesehatan Masyarakat, 8(2), 92-101.

Najoan, O. N., \& Tulusan, F. (2015). Efektifitas Sistem Komputerisasi Pada Kinerja Pegawai di Kecamatan Sonder. JURNAL ADMINISTRASI PUBLIK, 2(30).

Picauly, I., Mboeik, S. L., Lendes, T. S., \& Hayer, S. (2020). PENDAMPINGAN AKSI KONVERGENSI PERCEPATAN PENURUNAN STUNTING DI KABUPATEN MANGGARAI BARAT, PROPINSI NUSA TENGGARA TIMUR. JURNAL PENGABDIAN PADA MASYARAKAT KEPULAUAN LAHAN KERING, $1(2), 44-56$.

Priyatna, A. (2014). 1000 Hari Pertama Kehidupan. Elex Media Komputindo. Profita, A. C. (2018). Beberapa Faktor Yang Berhubungan Dengan Keaktifan Kader Posyandu Di Desa Pengadegan Kabupaten Banyumas. Jurnal Administrasi Kesehatan Indonesia, 6(2), 68-74.

Putri. (2018). Sosialisasi Sigizi Terpadu_EPPGBM. Retrieved from https://www.scribd.com/presentation/385623742/Sosialisasi-Sigizi- 


\section{Terpadu-EPPGBM}

Setiawan, E., Machmud, R., \& Masrul, M. (2018). Faktor-Faktor yang Berhubungan dengan Kejadian Stunting pada Anak Usia 24-59 Bulan di Wilayah Kerja Puskesmas Andalas Kecamatan Padang Timur Kota Padang Tahun 2018. Jurnal Kesehatan Andalas, 7(2), 275-284.

Sulistiyanti, A., \& Untariningsih, R. D. (2013). Hubungan Status Pekerjaan dengan Keaktifan Ibu Menimbangkan Balita di Posyandu Puri Waluyo Desa Gebang Kecamatan Masaran Kabupaten Sragen. Infokes: Jurnal Ilmiah Rekam Medis Dan Informatika Kesehatan, 3(2).

Susilawaty, D., \& Yulianto, A. (2018). WHO: 7,8 Juta Balita di Indonesia Penderita Stunting. Republika.Co.Id. Retrieved from https://www.republika.co.id/berita/nasional/umum/18/01/24/p30s85396 -who-78-juta-balita-di-indonesia-penderita-stunting

Tim Nasional Percepatan Penanggulangan Kemiskinan. (2017). 100 Kabupaten/Kota Prioritas untuk intervensi anak kerdil (stunting). Jakarta. Retrieved from http://www.tnp2k.go.id/images/uploads/downloads/Buku Ringkasan Stunting-1.pdf

Tse, A. D. P., Suprojo, A., \& Adiwidjaja, I. (2017). Peran kader posyandu terhadap pembangunan kesehatan masyarakat. JISIP: Jurnal Ilmu Sosial Dan Ilmu Politik, 6(1).

UNICEF. (2012). Ringkasan Kajian Gizi Oktober 2012 Ibu dan Anak. Jakarta. WHO; UNICEF; World Bank Group. (2018). LEVELS AND TRENDS IN CHILD MALNUTRITION. Retrieved from https://www.who.int/nutgrowthdb/2018-jme-brochure.pdf?ua=1\&ua=1

Wirapuspita, R. (2013). Insentif dan Kinerja Kader Posyandu. KEMAS: Jurnal Kesehatan Masyarakat, 9(1), 58-65.

Yanti, S. V., \& Kartini Hasballah, M. (2016). STUDI KOMPARATIF KINERJA KADER POSYANDU. Jurnal Ilmu Keperawatan, 4(2). 